\title{
EFFECT OF FIBRIN GLUE DERIVED FROM SNAKE VENOM ON THE VIABILITY OF AUTOGENOUS SPLIT-THICKNESS SKIN GRAFT
}

\author{
S.C. RAHAL ${ }^{1}$, M.S.P. AMARAL ${ }^{2}$, V.D. PAI ${ }^{2}$, S.R.C.S. BARRAVIERA ${ }^{3}$, E.H.G \\ CAPORALI ${ }^{1}$, A.J. CROCCI ${ }^{4}$
}

\begin{abstract}
${ }^{1}$ Department of Veterinary Surgery and Anesthesiology, Faculty of Veterinary Medicine and Animal Science, UNESP, Botucatu, São Paulo, Brazil; ${ }^{2}$ Faculty of Agrarian Science, UNOESTE, Presidente Prudente, São Paulo, Brazil; ${ }^{3}$ Department of Dermatology, Faculty of Medicine, UNESP, Botucatu, São Paulo, Brazil; ${ }^{4}$ Department of Biostatistics, Bioscience Institute, UNESP, Botucatu, São Paulo, Brazil.
\end{abstract}

ABSTRACT. The aim of this study was to analyze the effect of snake venom derived from fibrin glue on the viability of split-thickness skin graft. Nine crossbreed dogs were used. Fullthickness skin segments measuring 4 x $4 \mathrm{~cm}$ were bilaterally excised from the proximal radial area on each dog. A split-thickness skin graft was harvested from left lateral thoracic area using a freehand graft knife, and was secured to the left recipient bed using several simple interrupted sutures of 3-0 nylon (sutured graft). A split-thickness skin graft was harvested from the right lateral thoracic area using a graft knife. Fibrin glue derived from snake venom was applied to the recipient bed, and 8 equidistant simple interrupted sutures of 3-0 nylon were used to secure the skin graft (glued graft). Viable and nonviable areas were traced on a transparent sheet and measured using a Nikon Photomicroscope connected to a KS-300 image analysis system. The skin graft and recipient bed were collected from three dogs at day 7, 15, and 30 postoperative. The glued grafts had statistically higher graft viability than sutured grafts. Histological examination showed that the tissue repair process in the glued grafts was more accentuated than sutured grafts. It was possible to conclude that fibrin glue derived from snake venom increased survival of autogenous split-thickness skin graft.

KEY WORDS: fibrin glue, skin graft, snake venom, dogs.

CORRESPONDENCE TO: S. C. RAHAL - Department of Veterinary Surgery and Anesthesiology, Faculty of Veterinary Medicine and Animal Science, UNESP, Botucatu, Caixa Postal 560, 18618-000, Botucatu, São Paulo, Brazil. E-mail: sheilacr@fmvz.unesp.br 
S. C. Rahal et al. EFFECT OF FIBRIN GLUE DERIVED FROM SNAKE VENOM ON THE VIABILITY OF AUTOGENOUS SPLIT-THICKNESS SKIN GRAFT. J. Venom. Anim. Toxins incl. Trop. Dis., 2004, 10, 2, p.162.

\section{INTRODUCTION}

Fibrin glue is a biologic tissue adhesive that has been used for several years $(4,7)$ in numerous surgical procedures because of its haemostatic and adhesive properties $(1,9)$. There are two main components in fibrin glue. The first is fibrinogen, considered as the major portion, factor XIII and plasma proteins. The second is thrombin, calcium chloride, and aprotinin (9). Sealing results from the mixture of concentrated fibrinogen complex and bovine thrombin reconstituted in calcium chloride solution $(7,9)$. Fibrin adhesive is an effective haemostatic, because it induces the conversion of fibrinogen into fibrin resembling the last step of blood clotting, but it is indicated in low pressure bleeding (1). Since it does not depend on the presence of platelets or coagulation factors to be effective, it is useful in patients with hemorrhage from parenchymatous organs and coagulopathies (6).

Full and split thickness skin grafts and the donor area have been fixed using fibrin glue (1). It eliminates the dead space beneath skin graft and increases the probability of graft vascularization (17), increases adhesion and survival of skin grafts, reduces surgical time, and aids wound haemostasis (9). The number of sutures is decreased, reducing the possibility of scarring (17). Also, it has excellent tissue tolerance and is completely reabsorbed (1). Human patients with facial or hand burns that had been treated using fibrin glue showed improved haemostasis, early graft adherence, and better aesthetic results (15).

A new fibrin glue derived from snake venom has been developed by researchers from the Center for the Study of Venoms and Venomous Animals (CEVAP), UNESP. One advantage of this fibrin glue is to allow the use of homologous, heterologous, and autologous fibrinogen. It also uses a thrombin-like enzyme from snake venom that is several times more potent than bovine thrombin. The product has been used successfully in experimental reparation of peripheral nerves (5,21), rat colon anastomosis (8), testicular biopsy of rams (16), fixation of skin flaps (19), and fixation of skin grafting of the nasolabial folds in humans (18).

The aim of this study was to analyze the effect of fibrin glue derived from snake venom on the viability of split-thickness skin graft in dogs. 
S. C. Rahal et al. EFFECT OF FIBRIN GLUE DERIVED FROM SNAKE VENOM ON THE VIABILITY OF AUTOGENOUS SPLIT-THICKNESS SKIN GRAFT. J. Venom. Anim. Toxins incl. Trop. Dis., 2004, 10, 2, p.163.

\section{MATERIALS AND METHODS}

The Ethical Committee of the Faculty of Veterinary Medicine and Animal Science, UNESP Botucatu officially approved this research.

Nine crossbreed dogs were used with average age of 1.5 to 3 years old and weighing 8.0 to $15.0 \mathrm{~kg}$. The animals were confined to individual cages and received commercial pet food and water ad libitum.

After premedication with acepromazine ${ }^{1}(0.2 \mathrm{mg} / \mathrm{kg} / \mathrm{IV})$, general anesthesia was induced and maintained with sodium pentobarbital ${ }^{2}(15 \mathrm{mg} / \mathrm{kg} / \mathrm{IV})$. Both forelimbs and left and right lateral thoracic areas were prepared for aseptic surgery. The dogs were initially placed in right lateral recumbence. Full-thickness skin segment measuring 4 x $4 \mathrm{~cm}$ was excised from the left proximal radial area. Digital pressure and ligation of vessels were used to control hemorrhage. A split-thickness skin graft was harvested from left lateral thoracic area using a freehand graft knife. Sterile liquid vaseline was used to lubricate the skin. Graft size was calculated using a paper template obtained from the defect. The sheet graft was placed on the recipient bed with borders slightly overlapping those of the defect and was secured using several simple interrupted sutures of 3-0 nylon ${ }^{3}$ (sutured graft). The dogs were repositioned in left lateral recumbence. The surgical procedures on the right forelimb, left and right lateral thoracic areas were similar to those realized on the left forelimb. The difference was that snake venom derived fibrin glue was applied to the recipient bed, and only 8 equidistant simple interrupted sutures of 3-0 nylon were used to secure the skin graft (glued graft). Donor sites were not sutured, but treated only using saline solution.

The graft was covered with a first layer of rayon, a second layer of elastic gauze, and a third of elastic mesh. Saline solution was used to facilitate dressing removal; dressings were changed 3 and 7 days postoperative and thereafter every three or four days. Dressings were removed on day 15 postoperative. Sutures were removed 12 days after surgery.

\footnotetext{
${ }^{1}$ ACEPRAN $0^{\circledR}, 2 \%$ - Univet S.A.

2 HYPNOL ${ }^{\circledR} 3 \%$ - Cristália.

3 MONONYLON ETHILON 3-0 - Johnson \& Johnson.
} 
S. C. Rahal et al. EFFECT OF FIBRIN GLUE DERIVED FROM SNAKE VENOM ON THE VIABILITY OF AUTOGENOUS SPLIT-THICKNESS SKIN GRAFT. J. Venom. Anim. Toxins incl. Trop. Dis., 2004, 10, 2, p.164.

Enrofloxacin ${ }^{4}$ (5 mg/kg SC, q24 h) was administered before surgery and for the following 7 days. Buprenorphine ${ }^{5}(10 \mu \mathrm{g} / \mathrm{kg} \mathrm{IM}$, q8h) was administered preoperatively and for at least 3 days postoperatively. The dogs were maintained with Elizabethan collar and monitored daily.

Grafts were evaluated during dressing changes for signs of infection hematoma or seroma formation, and graft integration. Total and nonviable areas were traced on transparent sheet at 3, 7, 15 and 30 days postoperatively. Nonviable and total areas were measured using a Nikon Photomicroscope ${ }^{6}$ connected to a KS-300 image analysis system ${ }^{7}$. The graft survival area was obtained by subtraction of both. Areas that remained white or black in color, elevated from the graft bed and showed necrosis or retraction were considered nonviable.

For histological examination, the skin graft and recipient bed were harvested from three anesthetized dogs at day 7, 15, and 30 postoperative. Grafts were formalin fixed, paraffin embedded, and stained with Hematoxylin and eosin, and Masson’s trichrome. Also, recipient bed skin from two animals was processed to obtain control skin.

Percentages of viable and nonviable areas from the sutured and glued grafts were compared using repetitive measure analysis (22). A 5\% significance level was used.

\section{RESULTS}

The fibrin glue did not have enough adhesive power to fix the graft on its own, especially in the place where the wound was induced. However, the use of glue shortened operating time in comparison to suture alone. Graft borders overlying the defect borders always suffered necrosis. Adherence of graft edges at the first bandage change was noted in some grafts.

In the sutured graft hematoma formation was detected in two dogs, and seroma formation in the other two. In the glued graft seroma occurred in one dog. All hematomas and seromas were observed at day 3 after surgery. Needle puncture was used to drain them. Recurrence of one hematoma and one seroma was noted in the sutured graft at day 7 postoperative. Donor sites left without bandage developed protective crust, and total epithelialization was observed

\footnotetext{
4 BAYTRIL - Bayer S.A.

5 TENGESIC ${ }^{\circledR}$ - Indústria Química e Farmacêutica Schering-Plough S/A.

6 MICROPHOT-FXA.

7 KARL ZEISS VISION, Berlim, Alemanha.
} 
S. C. Rahal et al. EFFECT OF FIBRIN GLUE DERIVED FROM SNAKE VENOM ON THE VIABILITY OF AUTOGENOUS SPLIT-THICKNESS SKIN GRAFT. J. Venom. Anim. Toxins incl. Trop. Dis., 2004, 10, 2, p.165.

approximately two weeks after surgery.

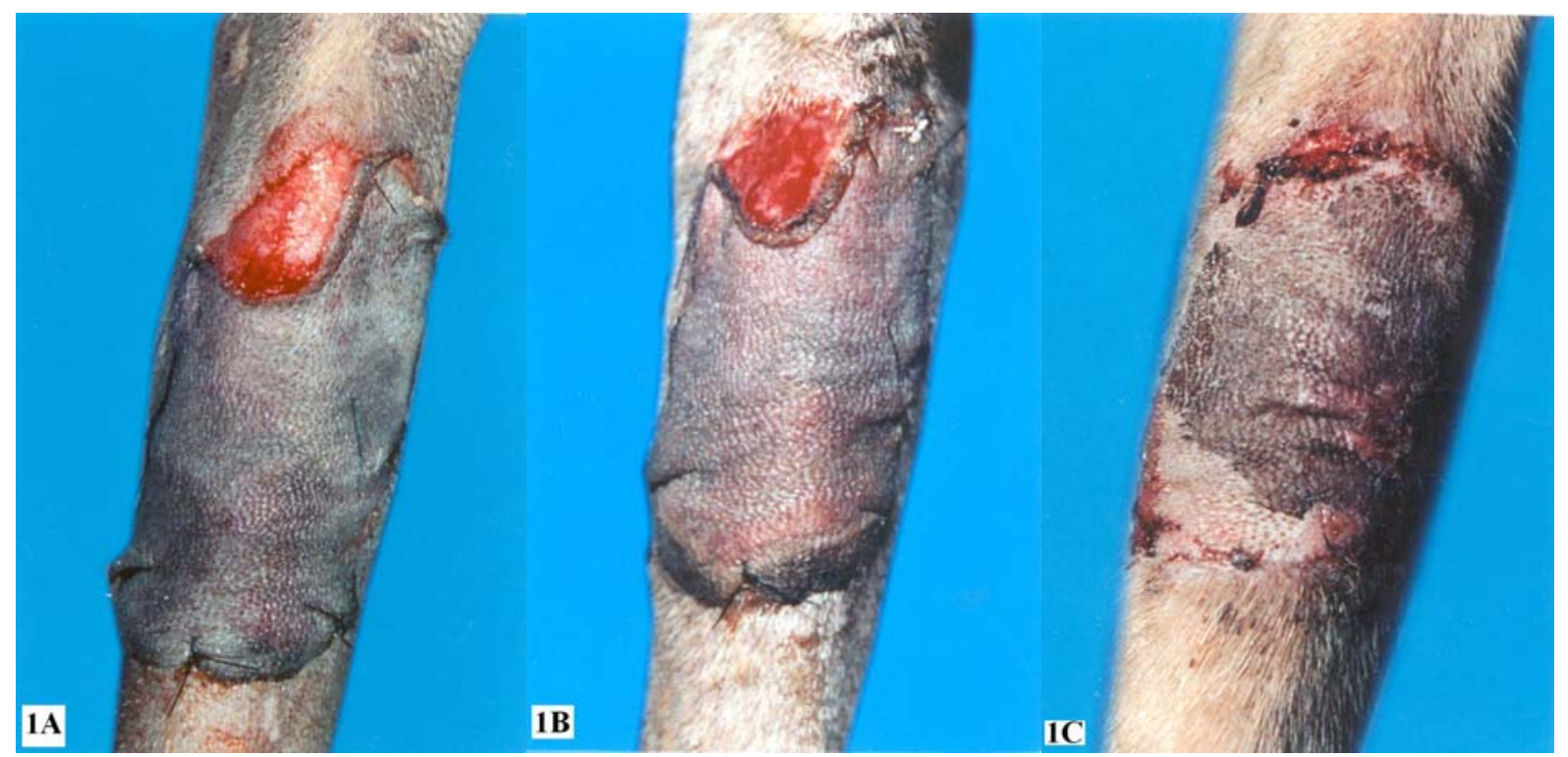

Figure 1. Glued graft macroscopic aspect at 3 (1A), 7 (1B), and 15 (1C) days postoperative. Graft proximal retraction is observed on days 3 and 7. However, the graft had almost 100\% survival area on day 15.

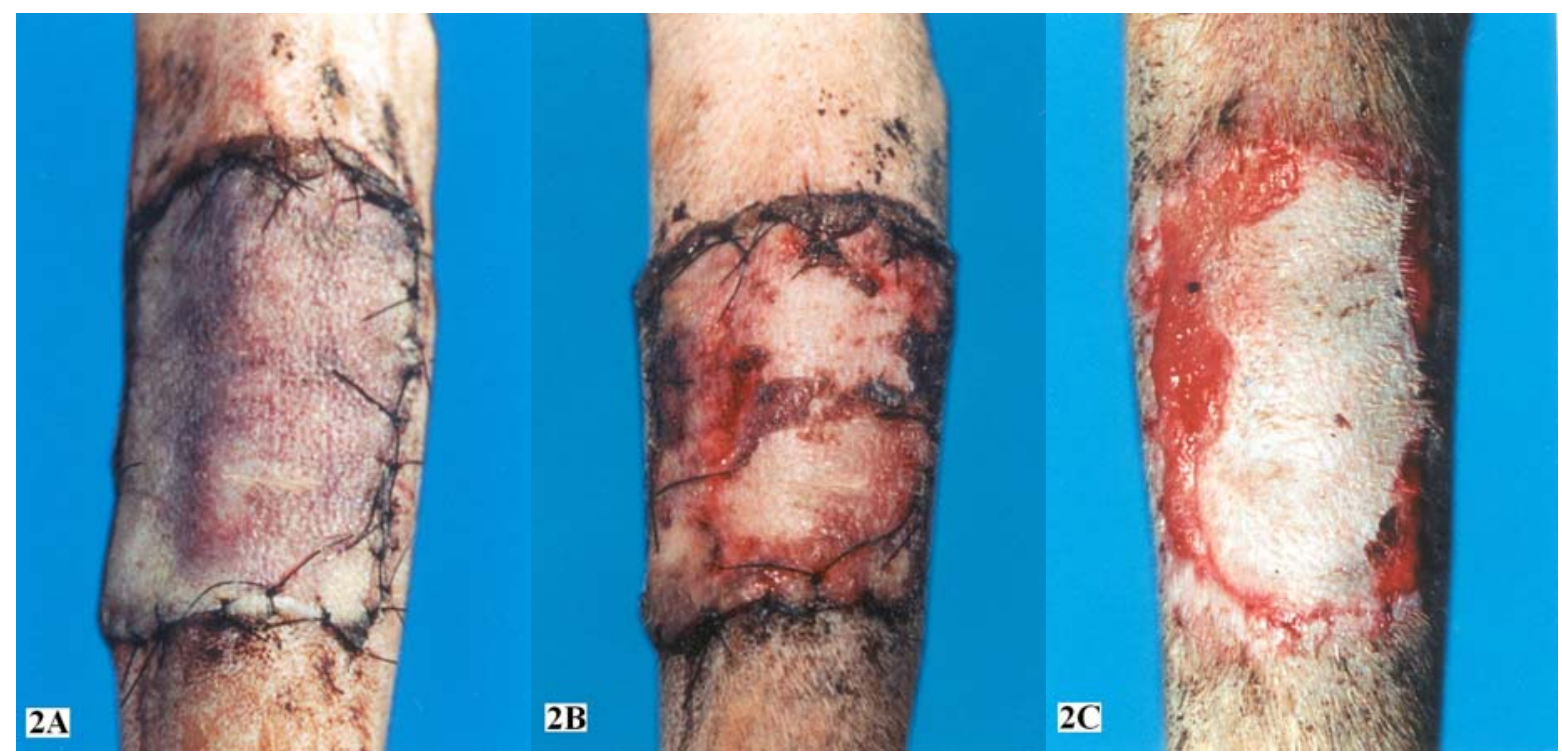

Figure 2. Sutured graft macroscopic aspect at 3 (2A), 7 (2B), and 15 (2C) days postoperative. White areas observed on day 3 became nonviable. The graft had almost $68 \%$ survival area on day 15. 
S. C. Rahal et al. EFFECT OF FIBRIN GLUE DERIVED FROM SNAKE VENOM ON THE VIABILITY OF AUTOGENOUS SPLIT-THICKNESS SKIN GRAFT. J. Venom. Anim. Toxins incl. Trop. Dis., 2004, 10, 2, p.166.

Significant difference in viability was observed at 7, 15 and 30 days after surgery (Table 1). The sutured graft had less viability than the glued graft (Figures 1 and 2). The percentage of viable areas of glued graft compared to sutured graft were $39.64 \%, 39.34 \%$, and $35.31 \%$ respectively at 7,15 , and 30 days postoperative. There were no significant differences between viable graft areas at the different evaluation times (Table 1).

Table 1. Mean percentage of viable graft by fixation technique and evaluation time (postoperative periods).

\begin{tabular}{|c|c|c|c|c|}
\hline \multirow[b]{2}{*}{ Fixation technique } & \multicolumn{4}{|c|}{ POSTOPERATIVE PERIODS } \\
\hline & $3^{\text {rd }}$ day & $7^{\text {th }}$ day & $15^{\text {th }}$ day & $30^{\text {th }}$ day \\
\hline Glued graft & $93.5 \mathrm{aA} *$ & 88.3aA & $84.4 \mathrm{aA}$ & $98.0 \mathrm{aA}$ \\
\hline Sutured graft & $73.4 \mathrm{aA}$ & $53.3 \mathrm{bA}$ & $51.2 \mathrm{bA}$ & $63.4 \mathrm{bA}$ \\
\hline
\end{tabular}

* Lower case letters: compare fixation techniques at each time Capital letters: compare moments in each fixation techniques Equal letters indicate no significant difference $(\mathrm{P}>0.05)$

The glued graft showed similar histological characteristics to the sutured graft, but tissue repair was more accentuated. By the $7^{\text {th }}$ day post surgery, the epithelium of the epidermis in the glued graft had more cellular layers and inflammatory cells (lymphocytes, polymorphonuclears and plasmocytes) than the sutured graft. The papillary layer of the dermis showed more cells, and the reticular layer had more delicate collagen fibers. There were many blood vessels surrounded by an increased number of cells. In the deep part of the reticular layer, there were many fibroblasts and fibrocytes indicating an intense synthesis process of collagen fibrils and amorph fundamental substance.

The epidermis of the glued graft was less thick at 15 days postoperative than 7 days. Compared to the sutured graft, the glued graft had more cells and a higher number of collagen fibers in the papillary layer of the dermis (Figures 3 and 4). The reticular layer showed dense conductive tissue with an elevated degree of organization. In the deep part of this layer, corresponding to the recipient bed, there was intense fibrosis with inflammatory cells especially around the vessels. The collagen fibers were oriented mostly in one direction. 
S. C. Rahal et al. EFFECT OF FIBRIN GLUE DERIVED FROM SNAKE VENOM ON THE VIABILITY OF AUTOGENOUS SPLIT-THICKNESS SKIN GRAFT. J. Venom. Anim. Toxins incl. Trop. Dis., 2004, 10, 2, p.167.

By the $30^{\text {th }}$ day after surgery, the epithelium of the epidermis in the glued graft, and the papillary and reticular layers of the dermis, had an aspect similar to the normal skin harvested from the recipient bed. In the deep part, corresponding to the recipient bed, there was extensive fibrosis, but this was less advanced than the dermis. The epithelium of the epidermis in the sutured graft was less thick than at 7 and 15 days. The papillary layer of the dermis showed advanced organization, but with reduced collagen fibers. In the part corresponding to the recipient bed there was extensive fibrosis, but it was less advanced than the papillary and reticular layers of the dermis.

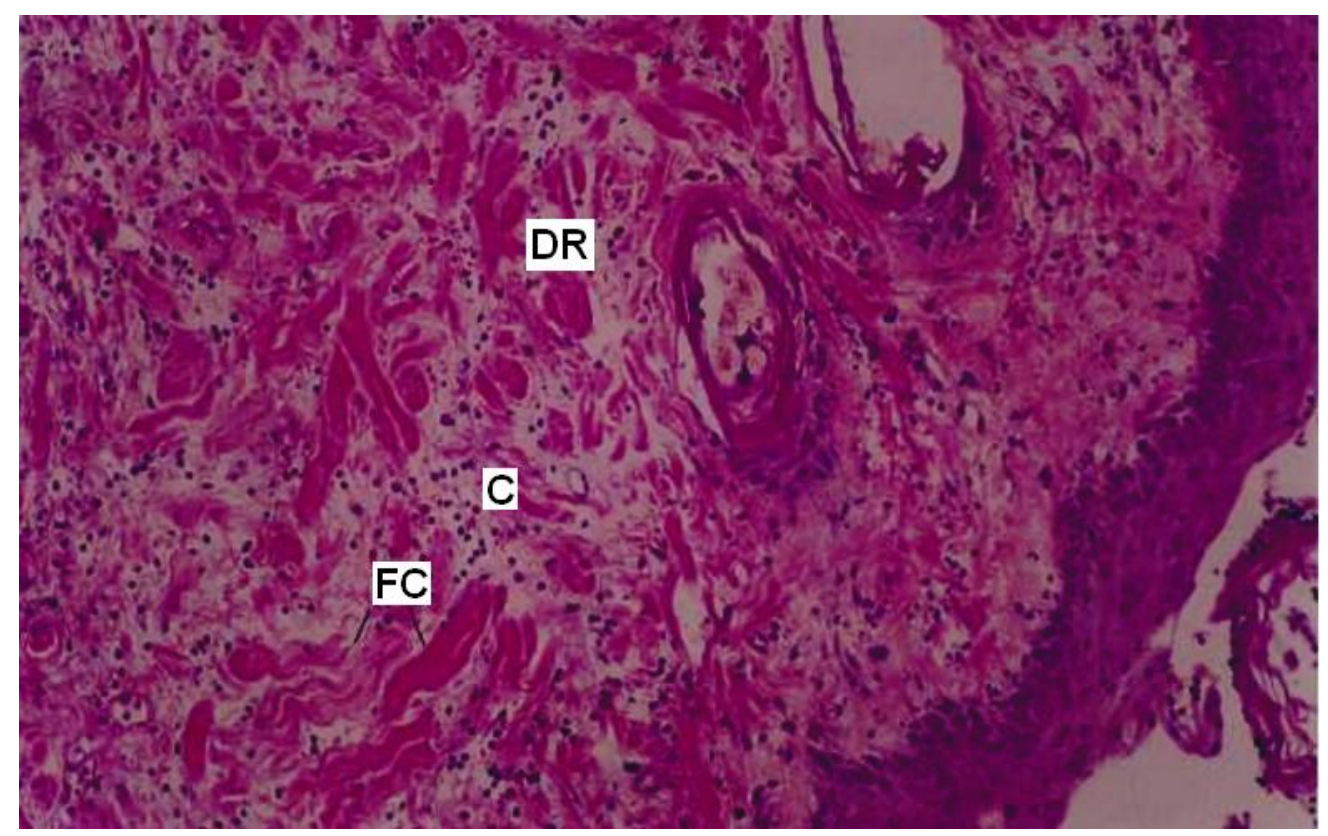

Figure 3. Histological appearance of the glued graft 7 days after surgery. Reticular layer of the dermis (DR) showing accentuated number of inflammatory cells, fibroblasts and fibrocytes. Deep part of the dermis showing delicate and thick collagen fibers (FC). Hematoxylin and eosin (x 42,8). 


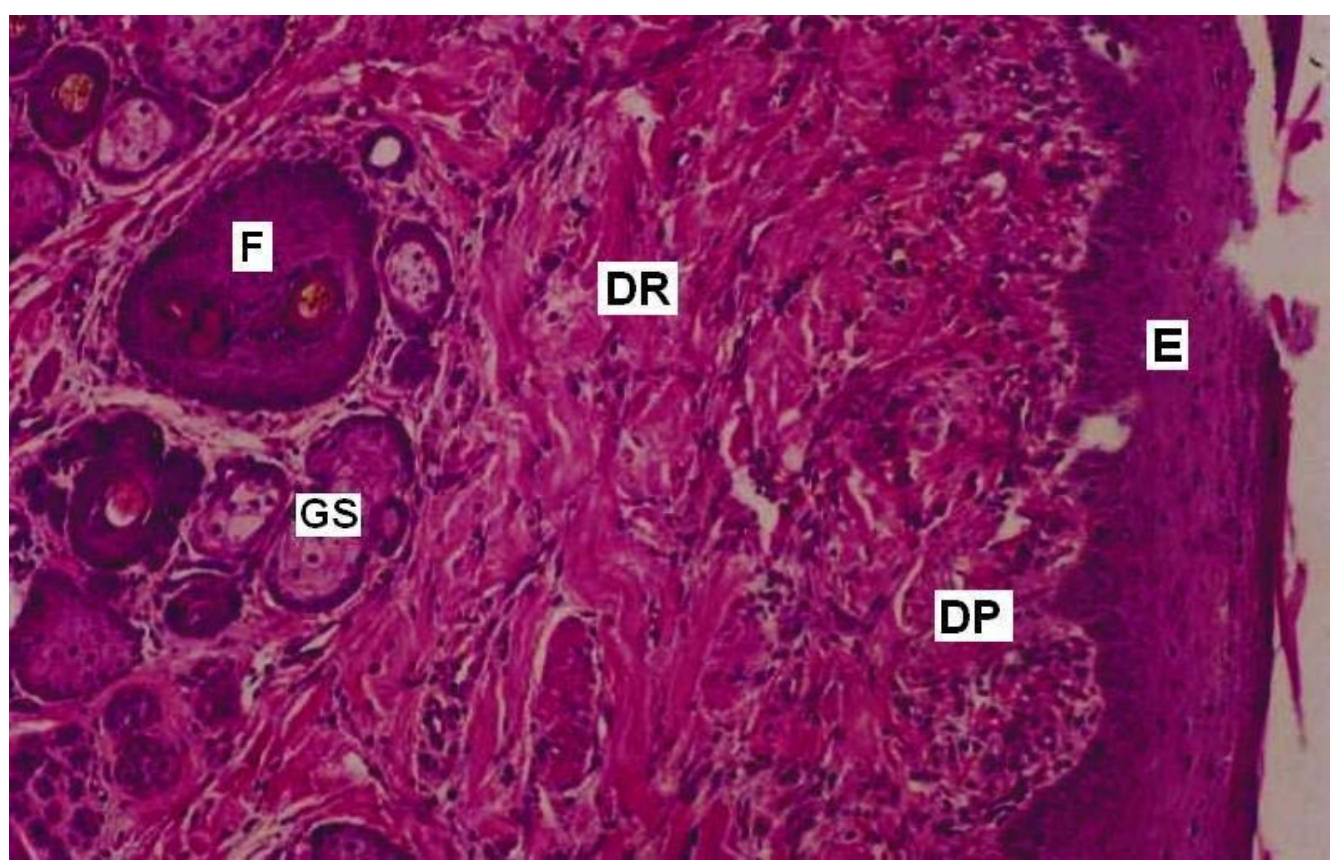

Figure 4. Histological appearance of the sutured graft 7 days after surgery Epidermis (E); papillary layer of the dermis (DP) showing elevated number of cells; reticular layer of the dermis (DR) showing fibrosis, moderate number of cells; hair follicles (F); sebaceous glands (GS). Hematoxylin and eosin (x 42,8).

\section{DISCUSSION}

Autogenous split-thickness skin grafts should be placed on a fresh clean wound or on a healthy granulation bed (14). However, a successful graft take is dependent on factors such as contact between the graft and recipient bed, and its immobilization with bandages, casts, or splints (12). Since there is a controversy about the best time to change bandages (14), the first change was made on the $3^{\text {rd }}$ day postoperative because, as per Swaim (20), the longer the intervals the less the risk of graft movement. Although some authors indicate antibiotic ointment or other medicines placed over or around the graft edges (13), in this experiment only nonadherent dressing (rayon) was used; this was due to the graft being unmashed, and to avoid the interference of ointments. The rayon had a good protective effect, but in some cases there was adherence to graft edges at first bandage change. 
S. C. Rahal et al. EFFECT OF FIBRIN GLUE DERIVED FROM SNAKE VENOM ON THE VIABILITY OF AUTOGENOUS SPLIT-THICKNESS SKIN GRAFT. J. Venom. Anim. Toxins incl. Trop. Dis., 2004, 10, 2, p.169.

The use of fibrin glue had important effect in reducing surgical time because it minimized the use of suture materials. This is an advantage especially for patients with high surgical risk $(1,9)$. The need to use sutures to help glue graft fixation and retraction occurring at the edge or corner proximal to the elbow joint, indicated that the fibrin glue derived from snake venom has low adhesion strength, especially in areas with movement. Also, Stolf (18) in nasolabial fold skin grafting in humans, noted that the fibrin glue derived from snake venom showed total adhesive capacity in $71.4 \%$ of patients and partial capacity in $28.6 \%$ of others.

The tensile or adhesive strength of fibrin glue is proportional to the fibrinogen content $(1,2,4)$; however, there may be inhibition of macrophage and neutrophil action with high concentration of fibrinogen and thrombin (2). At this moment, depending on wound size, the fibrin glue is favored as suture adjunctive rather than a total substitute (2). Further studies are necessary to determine the influence of higher concentrations of fibrinogen on wound healing. Also, the bandage may not have been able to perfectly immobilize the area. Maybe the results would have been better if the elbow joint had been completely immobilized, as suggested by Pope (13).

The two hematomas were only observed in the sutured graft, indicating that fibrin glue avoided hematoma formation because of its homeostatic properties $(1,3,6,9,11)$. On the other hand, although Lindsey et al. (10) and Harada et al. (4) had noted reductions in seroma formation using fibrin glue after mastectomy in rats, in our experiment there was one case in the glued and two in the sutured graft. Because seroma may develop when contact between graft and recipient bed is not maintained (12), bandage and glue adherence power could have been an influence in this experiment. However after drainage, the recurrence of one hematoma and one seroma occurred only in the sutured graft.

The statistical analysis confirmed that glued grafts showed higher viable area percentages than sutured grafts at 7, 15, and 30 days after surgery. This was similar to other authors $(9,15)$. However, it was different from a study that found retarded healing of open skin wounds in diabetic mice, probably caused by obstruction, mechanical inhibition, or both (7).

Histological examination revealed that the glued graft had similar characteristics to the sutured graft. However at all evaluation times, the healing pattern was better in the glued grafts. The enhancement of wound healing has been associated to the presence of fibronectin 
(1). The higher number of collagen fibers and cells observed in the glued graft at 15 days postoperative are very important in graft integration since, according to Pope (12), the fibrous tissue allows firm union between graft and recipient bed at around day 10. Also, on day 30 the glued grafts showed characteristics closer to normal skin than the sutured grafts. These findings are different from Saltz et al. (15) who did not note any difference in rat healing when the fibrin glue was compared to suture. On the other hand, Stolf et al. (19) reported better healing in cutaneous excision and rotation flaps in rabbits treated with fibrin glues. The fibrin glue used by Stolf et al. (19) was the same used in this study. Results may be influenced by differences in commercial glue composition $(4,9)$.

\section{CONCLUSION}

Fibrin glue derived from snake venom increases survival of autogenous split-thickness skin graft, but has moderate adhesive power.

\section{ACKNOWLEDGMENTS}

The authors are very grateful to the Research Support Foundation of São Paulo State FAPESP (No. 1999/08752-2) for financing this study, and to The Center for the Study of Venoms and Venomous Animals (CEVAP) for supplying the glue. They also wish to thank Dr. Izolete A. Thomazini Santos and Dr. Maria José S. Mendes Giannini for their assistance, and Dr. João Lauro Camargo Viana from the Department of Pathology, Faculty of MedicineUnesp Botucatu by the use of photomicroscope and image analyzer.

\section{REFERENCES}

1 BRENNAN M. Fibrin glue. Blood Ver., 1991, 5, 240-4.

2 BYRNE DJ., HARDY J., WOOD RAB., McINTOSH R., CUSCHIERI A. Effect of fibrin glues on the mechanical properties of healing wounds. Br. J. Surg., 1991, 78, 841-3. 
S. C. Rahal et al. EFFECT OF FIBRIN GLUE DERIVED FROM SNAKE VENOM ON THE VIABILITY OF AUTOGENOUS SPLIT-THICKNESS SKIN GRAFT. J. Venom. Anim. Toxins incl. Trop. Dis., 2004, 10, 2, p.171.

3 DEAN M., NICHOLLS M., WEDDERBURN C. Benefits of adjuvant fibrin glue in skin grafting. Med. J. Aust., 1994, 160, 526-7.

4 HARADA RN., PRESSLER VM., McNAMARA JJ. Fibrin glue reduces seroma formation in the rat after mastectomy. Surg. Gynecol. Obstet., 1992, 175, 450-4.

5 IUAN FC., THOMAZINI IA., GIANNINI MJSM., VITERBO F., TOSCANO E., MORAES RA., BARRAVIERA B. Reparation of peripheral nerves with fibrin glue prepared from snake venom. Preliminary results. São Paulo Med. J., 1995, 113, 1002.

6 KRAM HB., NATHAN RC., STAFFORD FJ., FLEMING AW., SHOEMAKER WC. Fibrin glue achieves hemostasis in patients with coagulation disorders. Arch. Surg., 1989, 124, 385-7.

7 LASA Jr. CI., KIDD RR., NUNEZ HA., DROHAN WN. Effect of fibrin glue and opsite on open wounds in D/B D/B mice. J. Surg. Res., 1993, 54, 202-6.

8 LEITE CVS., NARESSE LE., ARANTES HL., LOPES A.F., THOMAZINI-SANTOS IA., GIANNINI MJSM., MERCADANTE MC., BARRAVIEERA B., KOBAYASI S. An evaluation by rat colon anastomosis of the efficacy of fibrin glue derived from snake venom. J. Venom. Anim. Toxins, 2000, 6, 180-93. (SciELO)

9 LERNER R., BINUR NS. Current status of surgical adhesives. J. Surg. Res., 1990, 48, $165-81$.

10 LINDSEY WH., MASTERSON TM., SPOTNITZ WD., WILHELM MC., MORGAN RF. Seroma prevention using fibrin glue in a rat mastectomy model. Arch. Surg., 1990, 125, 305-7.

11 PIECHOTTA F., FLEMMING I. The maximization of wound healing with fibrin glue. Aesthetic. Plast. Surg., 1983, 7, 81-2.

12 POPE ER. Skin grafting in small animal surgery. Part I. The normal healing process. Compend. Small Anim., 1988a, 10, 915-23.

13 POPE ER. Skin grafting in small animal surgery. Part II. Full-thickness skin-grafting techniques. Compend. Small Anim., 1988b, 10, 1068-77. 
S. C. Rahal et al. EFFECT OF FIBRIN GLUE DERIVED FROM SNAKE VENOM ON THE VIABILITY OF AUTOGENOUS SPLIT-THICKNESS SKIN GRAFT. J. Venom. Anim. Toxins incl. Trop. Dis., 2004, 10, 2, p.172.

14 PROBST CW., PEYTON LC., BINGHAM HG., FOX SM. Split thickness skin grafting in the dog. J. Am. Anim. Hosp. Assoc., 1983, 19, 555-68.

15 SALTZ R., SIERRA D., FELDMAN D., SALTZ MB., DIMICK A., VASCONEZ LO. Experimental and clinical applications of fibrin glue. Plast. Reconstr. Surg., 1991, 88, 1005-15.

16 SARTORI-FILHO R., PRESTES NC., THOMAZINI IA., MENDES-GIANNINI MJS., TOSCANO E., CANAVESI AMO., BARRAVIERA B. Use of fibrin glue derived from snake venom in testicular biopsy of rams. J. Venom. Anim. Toxins, 1998, 4, 2335. (SciELO)

17 SILVER FH., WANG M., PINS GD. Preparation and use of fibrin glue in surgery. Biomaterials, 1995, 16, 891-903.

18 STOLF HO. The use of fibrin adhesive derived from snake venom and the evaluation of skin grafting using skin from the patient's nasolabial fold. J. Venom. Anim. Toxins, 1999, 5, 227. (SciELO)

19 STOLF HO., BARRAVIERA SRCS., THOMAZINI IA., GIANNINI MJMM., TOSCANO E., BARRAVIERA B. Cola de fibrina derivada de veneno de cobra. Uso experimental em cirurgia dermatológica. In: CONGRESSO BRASILEIRO DE DERMATOLOGIA, 48, Curitiba, 1993. Resumos...Curitiba: Sociedade Brasileira de Dermatologia, 1993. 168.

20 SWAIM SF. Skin grafts. Vet. Clin. North Am. Small Anim. Pract., 1990, 20, 147-74.

21 VITERBO F., THOMAZINI IA., GIANINI MJSM. Reparação de nervos periféricos com cola de fibrina derivada de veneno de cobra. Acta Cir. Bras., 1993, 8, 85.

22 ZAR JH. Biostatistical analysis. New Jersey: Prentice Hall, 1996. 718p. 